\title{
Population Briefs, Vol. 17, no. 3
}

Population Council

Follow this and additional works at: https://knowledgecommons.popcouncil.org/ series_newsletters_popbriefs How does access to this work benefit you? Let us know!

\section{Recommended Citation}

Population Briefs 17(3): New York: Population Council, 2011. 


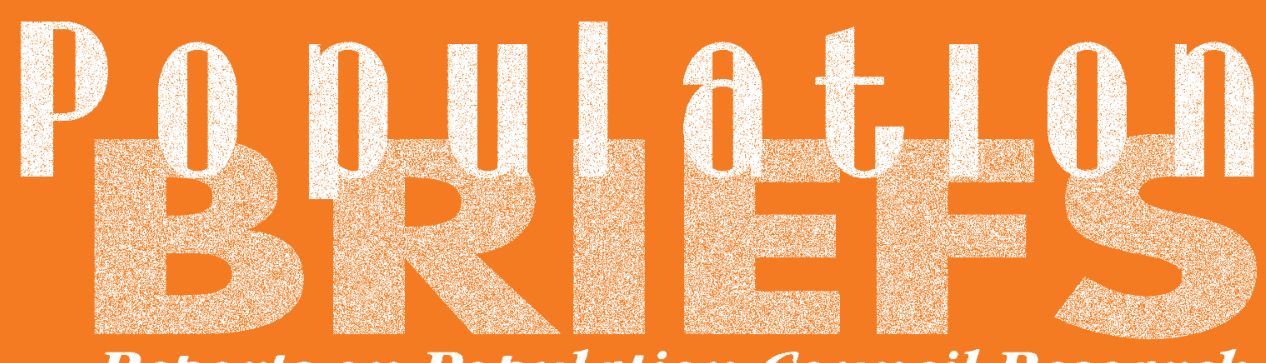

Reports on Population Council Research

December 2011 Volume 17, Number 3

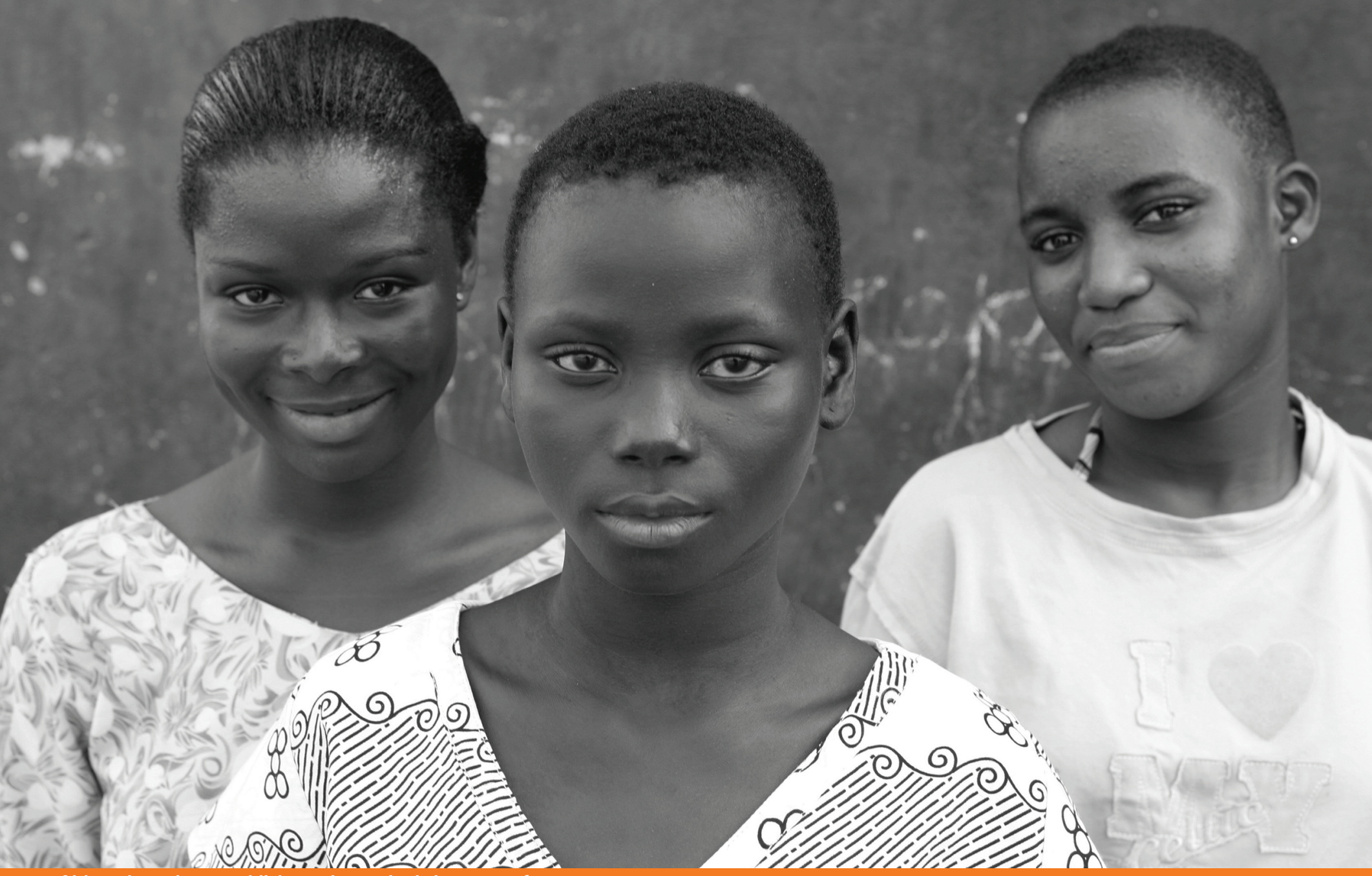

Although work to establish gender equity is important for all, we must focus scarce resources on those who are at the highest risk of the worst outcomes at the youngest ages. See story, page 8.

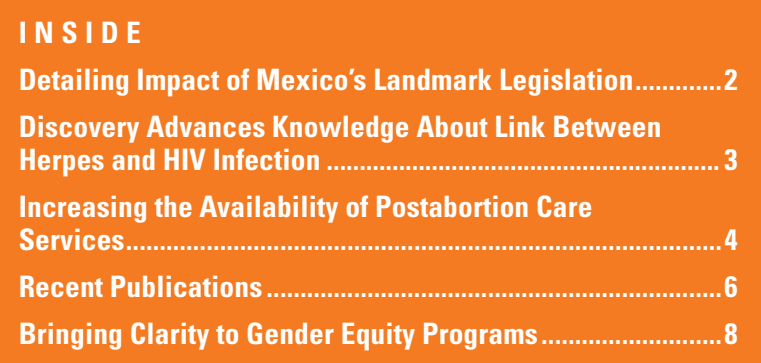




\section{Detailing Impact of Mexico's Landmark Legislation}

A recent special issue of one of the Population Council's peer-reviewed journals, Studies in Family Planning, describes the impact of Mexico City's landmark legislation to decriminalize first-trimester abortion.

In April 2007, Mexico City's legislative assembly voted to liberalize abortion law to permit the interruption of first-trimester pregnancies. Although the legislation was challenged, in August 2008 Mexico's Supreme Court ruled it constitutional. Since 2007, first-trimester abortion has been provided free of charge to Mexico City ing post-procedure contraceptive uptake among previous users - from 73 percent in 2007-08 to 85 percent by $2009-10$.

An article by Marieke van Dijk, a Population Council social scientist at the time of the research, and her colleagues presents qualitative data on the experiences of 25 women who underwent legal abortion. The in-depth interviews revealed that women were highly satisfied with the quality of the services provided in both public and private facilities, although some experienced difficulties finding a facility that

\section{The Population Council's research has been used to}

\section{shape policies and safeguard women's bealth.}

residents, and for a small fee to women from other Mexican states. "The Population Council's package of abortion-related research in Mexico has been used by government officials and women's rights advocacy groups to shape policies to safeguard women's health," says Sandra G. García, the Council's country director in Mexico. Latin America has some of the world's most restrictive abortion laws and the highest incidence of unsafe abortion. Complications of abortion are a major cause of maternal mortality in Latin America.

\section{Women's experiences}

An article by former Mexico City Minister of Health Manuel Mondragón y Kalb, Sandra García, and their colleagues presents data on the first 20,053 women served by 15 of the hospitals affiliated with the public sector abortion services program in its first three years. They found that the trend has been toward more medication and manual vacuum aspiration (MVA) abortions - procedures that can be employed very early in a pregnancy — and away from dilation and curettage, a procedure that results in more complications than medication or MVA abortion. The legal abortion program in Mexico City has also been successful in increas- offered the services. Most women felt they were treated respectfully during provision of service, approved of the contraceptive counseling they received, and adopted a method.

\section{Public and provider opinion}

Doctoral student and former Population Council researcher Kate S. Wilson and colleagues present the results of three opinion surveys conducted among Mexico City residents before and after the legal reform. The level of popular support for the proposed legislation prior to the reform had strongly influenced policymakers. The researchers found that support for the legalization increased significantly over the three years after it was enacted, from 38 percent in 2007 to 63 percent in 2008 and 74 percent in 2009. A similarly increasing percentage of respondents believe that the law should be extended to the rest of Mexico, from 51 percent in 2007 to 70 percent in 2008 and 83 percent in 2009.

Population Council researcher Xipatl Contreras and colleagues examined the experiences and opinions of health professionals. They found that while providers generally favor the provision of legal abortion, they feel that insufficient staffing and inadequately prepared facilities, combined with an increasing demand for services, compromised the implementation of the services. They further observed, however, that service provision has improved significantly over time.

Other articles describe surveys of public opinion outside of Mexico City_-finding, for example, that a large majority of respondents favored legal abortion in cases of rape (60 percent) and risk to a woman's life and health (65 percent and 60 percent, respectively) — and assess the Mexico City reform in the context of family planning and abortion policies, programs, and legal frameworks in several Latin American countries.

"The Council's research on ways to reduce unsafe abortion brings closer the goal of reducing pregnancy-related death and illness and improving the health of women around the world," says García.

\section{SOURCES}

Contreras, Xipatl, Marieke G. van Dijk, Tahilin Sanchez, and Patricio Sanhueza Smith. 2011. "Experiences and opinions of health-care professionals regarding legal abortion in Mexico City: A qualitative study," Studies in Family Planning 42(3): 183-190.

Langer, Ana. 2011. "Introduction to the Special Section on Abortion Legalization in Mexico City," Studies in Family Planning 42(3): 156-158.

Mondragón y Kalb, Manuel, Armando Ahued Ortega, Jorge Morales Velazquez, Claudia Díaz Olavarrieta, Jorge Valencia Rodríguez, Davida Becker, and Sandra G. García. 2011. "Patient characteristics and service trends following abortion legalization in Mexico City, 2007-10," Studies in Family Planning 42(3): 159-166.

Valencia Rodríguez, Jorge, Kate S. Wilson, Claudia Díaz Olavarrieta, Sandra G. García, and Maria Luisa Sánchez Fuentes. 2011. "Public opinion on abortion in eight Mexican states amid opposition to legalization," Studies in Family Planning 42(3): 191-198.

van Dijk, Marieke G., Luis Jorge Arellano Mendoza, Ana Gabriela Arangure Peraza, Aldo Alberto Toriz Prado, Abigail Krumholz, and Eileen A. Yam. 2011. "Women's experiences with legal abortion in Mexico City: A qualitative study," Studies in Family Planning 42(3): 167-174.

Wilson, Kate S., Sandra G. García, Claudia Díaz Olavarrieta, Aremis Villalobos-Hernández, Jorge Valencia Rodríguez, Patricio Sanhueza Smith, and Courtney Burks. 2011. "Public opinion on abortion in Mexico City after the landmark reform," Studies in Family Planning 42(3): 175-182.

\section{OUTSIDE FUNDING}

United Nations Population Fund (for Studies in Family Planning) 


\section{Discovery Advances Knowledge About Link Between Herpes and HIV Infection}

Recent Population Council research offers new insights on the biological events leading to HIV infection in people with genital herpes. The finding may provide scientists with new targets as they develop HIV prevention drugs.

\section{Genital herpes and HIV}

Little is known about what happens at the cellular level after HIV makes contact with the body. This lack of clarity delays the development of HIV prevention products. Scientists know that people with herpes simplex virus 2 (HSV-2) are three times more likely to contract HIV than people who do not have herpes. This increased rate of HIV infection is due in part to inflammation and ulcers caused by herpes infection, which allow HIV to pass into the body more easily.

But people with herpes are at higher risk for HIV even after they are treated to eliminate these symptoms. Thus, inflammation and ulcers are not the only cause of their increased risk of HIV infection. There is evidence that herpes infection can alter the function of the immune system, including its response to HIV.

\section{New strategies for preventing HIV}

Recent research led by the Population Council's Elena Martinelli and published in PLoS Pathogens, provides some clues about the role of genital herpes in HIV infection. More importantly, the research has revealed possible strategies for reducing HIV infection in people with genital herpes.

Martinelli and her colleagues found that when immune system cells known as dendritic cells are infected with HSV-2, HIV replication increases dramatically. Previous research at the Population Council described the critical role of dendritic cells in the onset of HIV infection.

HSV-2 infection of dendritic cells leads to increased HIV risk by ramping up production of retinoic acid. This increases the presence of the HIV receptor integrin $\alpha 4 \beta 7$ on T cells, which predisposes them to HIV infection. Integrin $\alpha 4 \beta 7$ then allows T cells to access intestinal tissues, where HIV replicates and spreads.

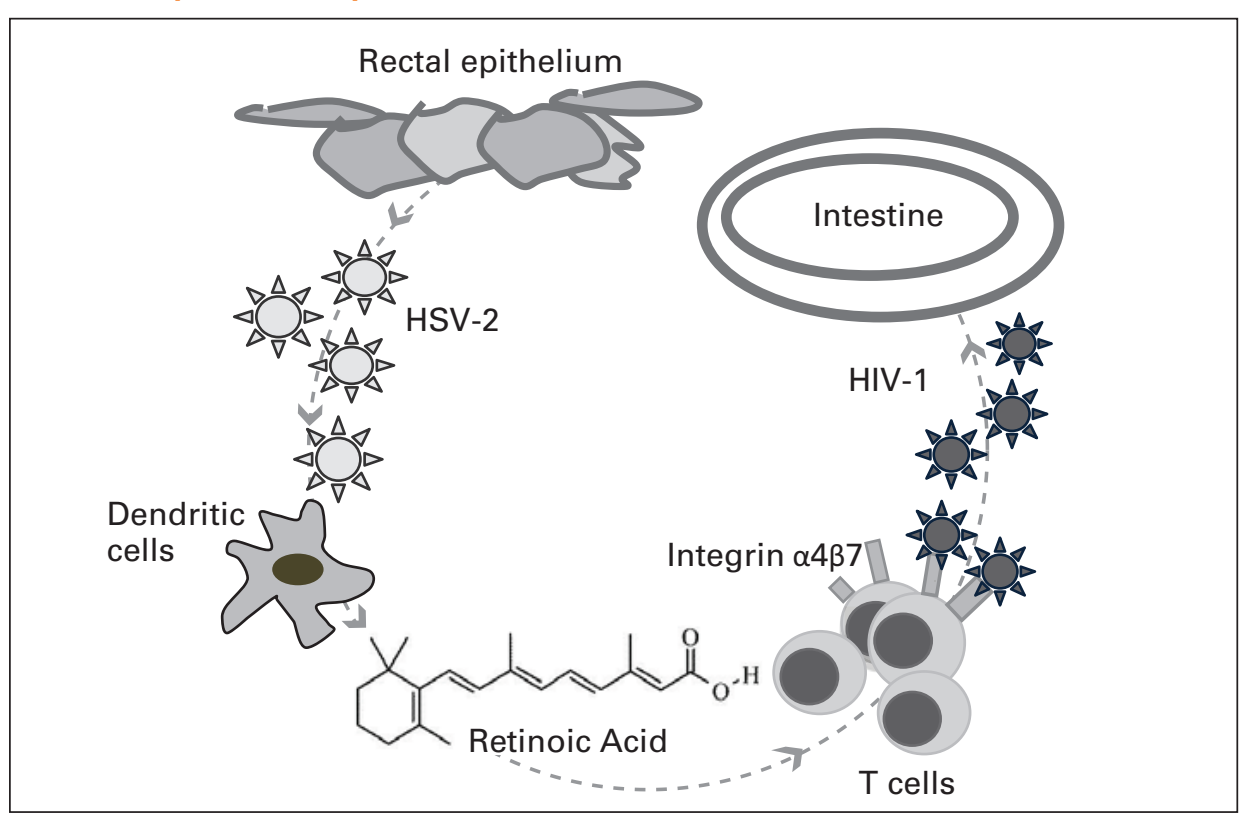

The new study shows that herpes infection increases the presence of two interconnected factors, retinoic acid and integrin $\alpha 4 \beta 7$, that play a role in HIV infection. Retinoic acid is a metabolite of vitamin A normally produced by dendritic cells in the digestive tract. The researchers found that HSV-2 infection of dendritic cells increases their production of retinoic acid.

Retinoic acid is known to increase the presence of integrin $\alpha 4 \beta 7$ on the surface of immune system cells called T cells. Martinelli and colleagues at the US National Institutes of Health previously demonstrated that integrin $\alpha 4 \beta 7$ is an HIV receptor, a molecule that allows HIV to enter cells. T cells possessing this receptor are highly susceptible to HIV infection.

\section{Complex interplay of molecules}

The researchers found that the number of $T$ cells expressing integrin $\alpha 4 \beta 7$ increases at the site of HSV-2 infection within six days of rectal exposure to HSV-2.

"Our studies show that HSV-2-infected dendritic cells secrete retinoic acid and thereby increase the presence of integrin $\alpha 4 \beta 7$ on $\mathrm{T}$ cells. Integrin $\alpha 4 \beta 7$ allows immune system cells (T cells) to access intestinal tissues, where HIV replicates and spreads. This sequence may result in an environment that heightens the susceptibility of people with genital herpes to HIV infection," says Martinelli. "Blocking the integrin $\alpha 4 \beta 7$ receptor might be a way to prevent some HIV infections among people with genital herpes."

\section{SOURCE}

Martinelli, Elena, Hugo Tharinger, Ines Frank, James Arthos, Michael Piatak Jr., Jeffrey D. Lifson, James Blanchard, Agegnehu Gettie, and Melissa Robbiani. 2011. "HSV-2 infection of dendritic cells amplifies a highly susceptible HIV-1 cell target." PLoS Pathogens 7(6): e1002109. doi:10.1371/journal.ppat.1002109.

\section{OUTSIDE FUNDING}

US National Institutes of Health 


\section{Increasing the Availability of Postabortion Care Services}

Complications arising from miscarriage

(spontaneous abortion) and incomplete induced abortion cause debilitating illness and injury and account for 13 percent of maternal deaths. Two major models of postabortion care (PAC) services have been developed to address this problem and improve health, one by the PAC Consortium and the other by the United States Agency for International Development. Yet, barriers remain to the expansion of PAC services in many countries. Increasing the availability of postabortion care services, especially in those settings where safe abortion services are restricted or limited, is crucial to reducing maternal mortality. Drawing on global experience, Population Council researchers recently identified the efforts needed to ensure that postabortion care services are scaled up and available to women who need them.

\section{What is postabortion care?}

Postabortion care is an integrated service that includes emergency treatment of complications, counseling, provision of contraceptives and reproductive health services, and community empowerment through awareness-raising and social mobilization. In order for a PAC service model to go to scale, it must be client-oriented, feasible, effective, and sustainable. Furthermore, the new service must be written into policy documents; service guidelines and standards must be developed and deployed; equipment must be provided; and providers must be trained.

Research has identified manual vacuum aspiration (MVA) and misoprostol administration as safe and effective emergency postabortion services that can be provided within existing health system budgets.

The most significant challenge is ensuring that every woman who receives postabortion care is also given information on her return to fertility and contraceptive options, and receives contraceptive services if she wants them. Additional challenges are providing a consistent and reliable supply of equipment and essential medications and ensuring the quality of postabortion care services once they have been introduced. Special training strategies are required for providers and their supervisors so that emergency services, counseling, and family planning services continue to be emphasized after training.

\section{Requirements for successful scale-up}

Several postabortion care service programs have been expanded nationally, most of them in Africa. The following four ingredients are vital to the successful scaling-up of postabortion care projects.

\section{Empirical evidence}

Data from multiple sources provide a comprehensive picture of women's needs, program responses and gaps, and funding requirements that policymakers can use as evidence to support scale-up of services. For example, women in many settings have reported appreciating the greater personal attention they receive when manual vacuum aspiration is provided in an office setting or lower-level facility.

\section{A policy champion}

The presence of a policy champion is essential for advocacy, setting the stage for the introduction of postabortion care services and subsequent scaling-up. Policy champions use available evidence to persuade such stakeholders as policymakers, legislators, and community advocates to take concerted action.

\section{A phased approach}

A phased approach is useful for a new service, especially one as socially and culturally sensitive as postabortion care. For example, after the first operations research study in Senegal in 1997-98 demonstrated the feasibility of postabortion care provision, national postabortion care protocols and norms were developed and disseminated and services were eventually decentralized to four regional hospitals and one district health center.

\section{Partnerships and community mobilization}

By engaging with communities - women, men, and community leaders - policymakers and program designers can build momentum for scaling up postabortion care services. Newer service delivery models emphasize community mobilization, not only to advocate for postabortion care services, but also to raise community awareness of the need for such services, to reduce stigma, and to find appropriate roles for all engaged community members.

"Working in partnership with the community, you can address women's reproductive

\section{"Unless we work}

together, we can't save

women's lives." health needs much more effectively," says Population Council researcher Saumya RamaRao, lead author of the recent review. "Unless we work together, we can't save women's lives."

\section{Much more work to be done}

Despite the advances made in the medical management of postabortion complications and the accumulation of evidence on the feasibility and sustainability of programs, much remains to be done. Continued progress in this critical reproductive health area will require sustained advocacy, political will, and steady service provision.

\footnotetext{
SOURCE

RamaRao, Saumya, John W. Townsend, Nafissatou Diop, and Sarah Raifman. 2011. "Postabortion care: Going to scale," International Perspectives on Sexual and Reproductive Health 37(1): 40-44.

OUTSIDE FUNDING

The William and Flora Hewlett Foundation
} 


\section{Selection of female and male participants: Ships in the night}

Of programs surveyed, more than half (64 percent) worked with both females and males, with a fourth working only with females and the rest working only with males. The vast majority of programs surveyed included young people; only 11 percent were for adults only. Forty percent focused exclusively on young people and very young adolescents (defined as those between ages 10 and 14). Strikingly, of the programs that work with both females and males, only 34 percent ever involved females in identifying appropriate male participants, that is, the males who have the largest impact on their lives with regard to the gender norms that the programs were meant to deal with. The researchers considered this a troubling use of scarce resources that arguably undermines program effectiveness.

\section{Confirming behavior changes with the affected parties}

The neglect of the female/male dynamic continues in monitoring and evaluation strategies. Of those programs that included males, 62 percent reported that they tried to assess whether men's gender attitudes or behaviors had changed as a result of their involvement in the program. A majority of these sought only males' self-reports (of being, for example, less likely to "abuse their partners" or more likely to "participate in household chores"). When probed, few programs that engaged males (13 percent) sought confirmation of the reported male changes directly from men's partners and peers. It is far from a standard practice.

Researchers assessed the gender-related components of each program independently and rated them based on three scales - a gender-continuum scale, a gender-alignment scale, and a genderelements indicator - that evaluate the extent to which the programs addressed specific issues. Not surprisingly, almost all (93 percent) of the genderand-HIV programs being assessed reported that they had a meaningful gender component. Only one-third of the programs, however, were found by the authors to have a clear focus on specific dimensions of male/female relations. Nor did program managers have a clear sense of how to work in parallel with males and females to resolve the issues between them or an explicit theory of change about how to improve gender relations.

But the authors did not despair as there were stand-outs, programs that began with a specific constituency (whether male or female), systematically identified challenges, and measured — responsibly and sometimes imaginatively_ c changes in females and males.

\section{Recommendations:}

\section{The value of clarity and synergy}

The researchers concluded their review with several recommendations. First, it is essential to have a clear hierarchy of values and to identify a core set of clients. The authors suggest that because HIV prevalence among adolescent females is several times higher than among males of this age, girls and young women deserve a larger share of preventive program resources and policy attention than they have been receiving.

Second, programs should select primary clients/participants deliberately and then determine secondary clients in relation to them. For example, start by identifying the females of interest, and then ask them to identify the males in their lives (for example, partners, fathers, brothers, peers, friends, clients) who are most crucial to their avoiding negative circumstances and achieving positive outcomes. Just as female core clients are a heterogeneous population, so are the males who are likely to be most consequential to their well-being.

"Programs need to tailor interventions as closely as possible to specific age, gender, and partnership status profiles. They need to learn from females what will make the most difference to them. And, they need to cross-check results when there is a parallel intervention among females and males. These procedures will lead to far more effective programs," said Haberland.

Finally, as an overarching need in the field, more rigorous and formal evaluation is required to determine whether burgeoning "gender" programs are working and for whom. Longitudinal studies are needed to assess change over longer periods of time and to evaluate the degree to which changes are sustained and in which populations. Whether males and females acquire new protective assets, skills, and perceptions and adopt positive behaviors can be verified at the level of both the participant and the community. Programs can measure reductions in the proportion of girls reporting that "a man is justified in beating his wife when she refuses sex." They can find out the proportion of girls who have an explicit understanding of the legal age of marriage and the legal status of female genital mutilation. Programs can determine whether female populations at risk have specific plans about, for example, protecting themselves when attending school or how to respond when danger or pressure arises in a relationship. In couples - for example, young married couples expecting a first birth or couples with a history of violence- both males' and females' perceptions and actions should be accounted for.

Measuring changes in "violence" per se is tricky; violence can be a moving target. As females (and males) become more sensitive to rights and appropriate boundaries, reports of violence and abusive behaviors may increase because females feel greater permission to report them or they begin to define behaviors that were previously accepted as less acceptable. Furthermore, violent incidents themselves may increase as females begin to behave more freely before the males in their lives accept these changes. Reductions in structural violence (such as child marriage, as there is an objective standard of age at marriage, or female genital mutilation, as females are either circumcised to some degree or not) are more easily measured in the context of community-level approaches.

"Investing in improving the norms and behaviors of both females and males is important, but these programs must approach these investments with a clear sense of where home base is," said Bruce. "Prioritizing the allocation of resources to the most vulnerable people is crucial to program success, and it is an ethical imperative."

\section{SOURCE}

Bruce, Judith, Nicole Haberland, Amy Joyce, Eva Roca, and Tobey Nelson Sapiano. 2011. “First generation of gender and HIV programs: Seeking clarity and synergy," Poverty, Gender, and Youth Working Paper no. 23. New York: Population Council.

\section{OUTSIDE FUNDING}

Ford Foundation, Nike Foundation, and UK Department for International Development (DFID) 


\section{HIV AND AIDS}

Barone, Mark, Frederick Ndede, Philip S. Li, Puneet Masson, Quentin Awori, Jairus Okech, Peter Cherutich, Nicholas Muraguri, Paul Perchal, Richard Lee, Howard H. Kim, and Marc Goldstein. "The Shang Ring device for adult male circumcision: A proof of concept study in Kenya," Journal of Acquired Immune Deficiency Syndromes 57(1): e7-e12.

Begay, Othell, Ninochka Jean-Pierre, Ciby J. Abraham, Anne Chudolij, Samantha Seidor, Aixa Rodriguez, Brian E. Ford, Marcus Henderson, David Katz, Thomas M. Zydowsky, Melissa Robbiani, and Jose A. Fernandez-Romero. "Identification of personal lubricants that can cause rectal epithelial cell damage and enhance HIV-1 replication in vitro," AIDS Research and Human Retroviruses 27(9): 1019-1024.

Brady, Martha and Heeyoung Park. "What regulatory guidance exists for multipurpose prevention technologies (MPTs)? A review of key guidance documents and their applicability to MPTs." Washington, DC: Population Council.

Derby, Nina R., Elena Martinelli, and Melissa Robbiani. "Myeloid dendritic cells in HIV-1 infection," Current Opinion in HIV and AIDS 6(5): 379-384.

Friedland, Barbara A., Louis Apicella, Katie D. Schenk, Meredith Sheehy, and Paul C. Hewett. "Evaluation of the informed consent process for male circumcision scale-up in Swaziland," Population Council Research and Evaluation of Male Circumcision Scale-up Report no. 3. New York: Population Council.

Kalibala, Sam and Drosin Mulenga. "Situation assessment of the HIV response among young people in Zambia." Geneva: UNAIDS.

Kalibala, Sam, Waimar Tun, William Muraah, Peter Cherutich, Erick Oweya, and Patricia Oluoch. "'Knowing myself first': Feasibility of self-testing among health workers in Kenya." Nairobi: Population Council.

Katzen, Lauren, Jose A. Fernandez-Romero, Avina Sarna, Kailapuri G. Murugavel, Daniel Gawarecki, Thomas M. Zydowsky, and Barbara S. Mensch. "Validation of a dye stain assay for vaginally inserted hydroxyethylcellulose-filled microbicide applicators," Sexually Transmitted Diseases 38(11): 1050-1055.

Saggurti, Niranjan, Bidhubhusan Mahapatra, Suvakanta N. Swain, Madhusudana Battala, Umesh Chawla, and Alka Narang. "HIV transmission among married men and women in districts with high outmigration in India: Study brief." New Delhi: UNDP, NACO, and Population Council.

Saggurti, Niranjan, Bidhubhusan Mahapatra, Suvakanta N. Swain, Madhusudana Battala, Alka Narang, and Umesh Chawla. "Migration and HIV in India: Study of select districts." New Delhi: UNDP, NACO, and Population Council.

Saggurti, Niranjan, Ravi K. Verma, Shiva S. Halli, Suvakanta N. Swain, Rajendra Singh, Hanimi Reddy Modugu, Saumya RamaRao, Bidhubhusan Mahapatra, and Anrudh K. Jain. "Motivations for entry into sex work and HIV risk among mobile female sex workers in India," Journal of Biosocial Science 43(5): 535-554.

Whitehead, Sara J., Catherine A. McLean, Supaporn Chaikummao, Sarah Braunstein, Wat Utaivoravit,
Janneke van de Wijgert, Philip A. Mock, Taweesap Siraprapasiri, Barbara A. Friedland, Peter H. Kilmarx, and Lauri Markowitz. "Acceptability of Carraguard vaginal microbicide gel among HIV-infected women in Chiang Rai, Thailand," PLoS ONE 6(9): e14831.

\section{POVERTY, GENDER, AND YOUTH}

Amin, Sajeda. "Enhancing the benefits of girls' livelihood initiatives," Promoting Healthy, Safe, and Productive Transitions to Adulthood Brief no. 17. New York: Population Council.

\section{- "Programs to address child marriage:}

Framing the problem," Promoting Healthy, Safe, and Productive Transitions to Adulthood Brief no. 14. New York: Population Council.

Amin, Sajeda and Althea D. Anderson. "Abordar la violencia sexual basada en el género (SGBV) contra niñas adolescentes," Promoción de transiciones a la vida adulta sanas, seguras y productivas resumen no. 38. New York: Population Council.

Austrian, Karen. "Expanding safe spaces, financial education, and savings for adolescent girls in Kenya," Promoting Healthy, Safe, and Productive Transitions to Adulthood Brief no. 29. New York: Population Council. (also published in French)

Austrian, Karen and Dennitah Ghati. "Diseño de un Programa Centrado en las Niñas: Un juego de herramientas para desarrollar, fortalecer y expandir programas para niñas adolescentes." Nairobi: Population Council. (also published in English and French)

Baldwin, Wendy. "Creación de 'espacios seguros' para niñas adolescentes," Promoción de transiciones a la vida adulta sanas, seguras y productivas resumen no. 39. New York: Population Council.

Brady, Martha. "Ampliación de programas para adolescentes vulnerables: Experiencias, entendimientos y evidencia," Promoción de transiciones a la vida adulta sanas, seguras y productivas resumen no. 36. New York: Population Council.

_. "Leveling the playing field: Building girls' sports programs and creating new opportunities," Promoting Healthy, Safe, and Productive Transitions to Adulthood Brief no. 1. New York: Population Council.

Catino, Jennifer, Alejandra Colom, and Marta Julia Ruiz. "Equipping Mayan girls to improve their lives," Promoting Healthy, Safe, and Productive Transitions to Adulthood Brief no. 5. New York: Population Council. (also published in Spanish)

El-Kogali, Safaa. "Education during humanitarian emergencies: The situation of displaced children and youth in Darfur, Sudan," Promoting Healthy, Safe, and Productive Transitions to Adulthood Brief no. 32. New York: Population Council.

Engebretsen, Sarah and Selina Esantsi. "Pilotage d'un programme visant à sécuriser l'espace et à renforcer les ressources des adolescentes vivant dans les zones urbaines du Ghana," Promouvoir des transitions vers l'âge adulte saines, sécurisées et productives resumen no. 40. New York: Population Council.
Engebretsen, Sarah and Gisele Kabore. "Addressing the needs of girls at risk of early marriage and married adolescent girls in Burkina Faso," Promoting Healthy, Safe, and Productive Transitions to Adulthood Brief no. 9. New York: Population Council. (also published in French)

Erulkar, Annabel S., Louis Apicella, and Abebaw Ferede. "Addis Birhan project: Working with boys and men to address young girls' social vulnerability," Promoting Healthy, Safe, and Productive Transitions to Adulthood Brief no. 6. New York: Population Council.

Erulkar, Annabel S., Belaynesh Semunegus, and Gebeyehu Mekonnen. "Biruh Tesfa provides domestic workers, orphans, and migrants in urban Ethiopia with social support, HIV education, and skills," Promoting Healthy, Safe, and Productive Transitions to Adulthood Brief no. 21. New York: Population Council. (also published in French)

Grant, Monica J., Barbara S. Mensch, and Mary Philip Sebastian. "Introducing adolescent livelihoods training in the slums of Allahabad, India," Promoting Healthy, Safe, and Productive Transitions to Adulthood Brief no. 2. New York: Population Council.

Haberland, Nicole, Deborah Rogow, Ofelia Aguilar, Doortje Braeken, Jessie Clyde, Caroline Earle, Denise Kohn, Bene Madunagu, Grace Osakue, and Corinne Whitaker. Un Sólo Currículo: Pautas y Actividades Para un Enfoque Integrado Hacia la Educación en Sexualidad, Género, VIH y Derechos Humanos. Nicole Haberland and Deborah Rogow (eds.). New York: Population Council. (also published in English and French)

Hallman, Kelly and Eva Roca. "Siyakha Nentsha: Building economic, health, and social capabilities among highly vulnerable adolescents in KwaZuluNatal, South Africa," Promoting Healthy, Safe, and Productive Transitions to Adulthood Brief no. 4. New York: Population Council.

Jejeebhoy, Shireen J. "Protecting young people from sex without consent," Promoting Healthy, Safe, and Productive Transitions to Adulthood Brief no. 7. New York: Population Council.

Kabore, Gisele, Kotalama Traore, and Saidou Dipama. 2010. "Éliminer le mariage des enfants: Expérience pilote dans cinq régions du Burkina Faso." Ouagadougou: Population Council.

Lloyd, Cynthia B. "Girls' schooling in developing countries: Highlights from Population Council research," Promoting Healthy, Safe, and Productive Transitions to Adulthood Brief no. 24. New York: Population Council. (also published in Spanish)

Population Council. 2010. "Données démographiques pour développement II-De la recherche à l'intervention: améliorer l'accès et l'utilsation des données par les médias," Poverty, Gender, and Youth Policy Brief no. 2. New York: Population Council.

Population Council and Microfinance Opportunities. Young Women: Your Future, Your Money—Workbook for Girls Ages 15-19 in Kenya. Nairobi: Microfinance Opportunities, Population Council, and MicroSave Consulting, Ltd.

- Young Women: Your Future, Your MoneyWorkbook for Girls Ages 15-19 in Uganda. Nairobi: Microfinance Opportunities, Population Council, and MicroSave Consulting, Ltd. 
Young Women: Your Future, Your MoneyWorkbook for Girls Ages 10-14 in Kenya. Nairobi: Microfinance Opportunities, Population Council, and MicroSave Consulting, Ltd.

Young Women: Your Future, Your MoneyWorkbook for Girls Ages 10-14 in Uganda. Nairobi: Microfinance Opportunities, Population Council, and MicroSave Consulting, Ltd.

"The Population Council's approach: Promoting healthy, safe, and productive transitions to adulthood," Promoting Healthy, Safe, and Productive Transitions to Adulthood Overview. New York: Population Council. (also published in French and Spanish)

Undie, Chi-Chi. "Addressing sexual violence and HIV risk among married adolescent girls in rural Nyanza, Kenya," Promoting Healthy, Safe, and Productive Transitions to Adulthood Brief no. 19. New York: Population Council.

\section{REPRODUCTIVE HEALTH}

Acquiring Skills in Family Planning Service Delivery for Medical Students: Trainer's Notebook. Islamabad: Population Council.

Bellows, Benjamin, Charlotte Warren, Saphonn Vonthanak, Chhea Chhorvann, Hean Sokhom, Chean Men, Ashish Bajracharya, Ubaidur Rob, and Tung Rathavy. "Evaluation of the impact of the voucher and accreditation approach on improving reproductive behaviors and status in Cambodia," BMC Public Health 11: 667

"Birth spacing and family planning in Pakistan: Lady health visitor student's handbook." Islamabad: Population Council.

"Birth spacing and family planning in Pakistan Midwifery student's handbook." Islamabad: Population Council.

"Birth spacing and family planning in Pakistan: Nursing student's handbook." Islamabad: Population Council.

Birungi, Harriet, Francis Obare, Anke van der Kwaak, and Jane H. Namwebya. "Maternal health care utilization among HIV-positive female adolescents in Kenya," International Perspectives on Sexual and Reproductive Health 37(3): 143-149.

Client Centered Family Planning Services (Advanced): Trainer's Manual. Islamabad: Population Council.

Client Centered Family Planning Services (Basic): Participant's Manual. Islamabad: Population Council.

Client Centered Family Planning Services (Basic) Trainer's Manual. Islamabad: Population Council.

Competency Based Clinical Skills for IUCD:

Participant's Manual. Islamabad: Population Council.

Competency Based Clinical Skills for IUCD: Trainer's Notebook. Islamabad: Population Council.

Counseling an FP Client/Safe Injection Practices/ Overview of Minilap Procedure: Student's Notebook. Islamabad: Population Council.

Developing Problem Solving in Family Planning Service Provision: Student's Notebook. Islamabad: Population Council.
Directorate General of Health Services (DGHS), Population Council, and UNICEF Bangladesh. 2010. "Guidelines for pilot study on introducing pay-forperformance (P4P) approach to increase utilization of maternal, newborn and child health services in Bangladesh." Dhaka: DGHS, Population Council, and UNICEF.

Foreit, James R. and Sarah Raifman. "Increasing access to family planning (FP) and reproductive health $(\mathrm{RH})$ services through task-sharing between community health workers ( $\mathrm{CHWs}$ ) and community mid-level professionals in large-scale public-sector programs: A literature review to help guide case studies." Washington, DC: Population Council.

Hu, Guo-Xin, Binghai Zhao, Yanhui Chu, X.H. $\mathrm{Li}$, Benson T. Akingbemi, Zhi-Qiang Zheng, and Renshan Ge. "Effects of methoxychlor and 2,2-bis( $p$-hydroxyphenyl)-1,1,1-trichloroethane on $3 ß$-hydroxysteroid dehydrogenase and 17ß-hydroxysteroid dehydrogenase- 3 activities in human and rat testes," International Journal of Andrology 34(2): 138-144.

Introduction of E-Learning Module/Practical Skills of IUCD Insertion/Removal/Instruments Processing Student's Notebook. Islamabad: Population Council.

Manual of National Standards for Family Planning Services. Islamabad: Population Council.

Merkatz, Ruth B. and Elyse I. Summers. "Nursing's influence on drug development and safety," in Diana J. Mason, Judith K. Leavitt, and Mary W. Chaffee (eds.), Policy \& Politics in Nursing and Health Care, Sixth Edition. St. Louis: Saunders, pp. 231-239.

Module for Community Medicine Department: Student's Notebook. Islamabad: Population Council.

Module on Normal Physiology of Menstrual Cycle: Student's Notebook. Islamabad: Population Council.

Overview of Contraceptive Methods/Basic Infection Prevention Practices (Hand Washing): Student's Notebook. Islamabad: Population Council.

Population Council. 2010. "Brief report: Activities and achievements of the P4P Project." Dhaka: Population Council.

2010. "Intégration des Services au Sénégal," brief. Dakar: Population Council.

2010. "Rôle du secteur privé dans l'offre de services de santé au Sénégal," brief. Dakar: Population Council.

2010. "A strategy for the reduction of maternal and neonatal mortality," brief. Dakar: Population Council. (also published in French)

2010. "Une bonne surveillance de la grossesse pour préparer l'accouchement," brief. Dakar: Population Council.

Rahman, Laila, Dipak Kumar Shil, Mamun-orRashid, Ismat Ara Hena, Md. Noorunnabi Talukder, Farhana Akter, Anup Kumar Dey, Ripa Ali, Joynal Abedin, Mursheda Rahman, Md. Ataur Rahman, Md. Julkarnayeen, Arifur Rahman, and Md. Abdur Rab Sardar. 2010. "Manual on financial mechanism for the health facilities: Introducing pay-for-performance approach to increase utilization of maternal, newborn, and child health services in Bangladesh." Dhaka: Population Council.
Raifman, Sarah, Ian Askew, Sajeda Amin, Jill Keesbury, Saiqa Mullick, Judith A. Diers, Meiwita P. Budiharsana, Chi-Chi Undie, Mary Zama, Mantshi Menziwa, Sherry Hutchinson, and Naomi Rutenberg. "The prevention and management of HIV and sexual and gender-based violence: Responding to the needs of survivors and those-at-risk." Washington, DC: Population Council.

Rob, Ubaidur, Md. Moshiur Rahman, and Benjamin Bellows. "Evaluation of the impact of the voucher and accreditation approach on improving reproductive behaviors and $\mathrm{RH}$ status: Bangladesh," BMC Public Health 11(1): 257

"Scaling up access to quality family planning and safe abortion services," STEP UP Fact Sheet, April 2011. New York: Population Council. (also published in French)

Shah, Zakir Hussain. 2010. "Process evaluation of community mobilization activities." Islamabad: Population Council.

Social Mobilization Strategy. Islamabad: Population Council.

Talukder, Md. Noorunnabi, Ubaidur Rob, Ismat Ara Hena, Farhana Akter, Mohammad Ataur Rahman, and Md. Julkarnayeen. 2010. "Workshop report: Introducing pay-for-performance (P4P) approach to increase utilization of maternal, newborn, and child health services in Bangladesh." Dhaka: Population Council.

Talukder, Md. Noorunnabi, Ubaidur Rob, Laila Rahman, Ismat Ara Hena, Farhana Akter, Mohammad Ataur Rahman, Md. Julkarnayeen, Md. Akteruzzaman, Md. Sohel Rana, and Ripa Ali. 2010. "Facility assessment report: Introducing pay-for-performance (P4P) approach to increase utilization of maternal, newborn, and child health services in Bangladesh." Dhaka: Population Council.

"Using community health workers can lead to positive sexual behavior outcomes among people living with HIV," APHIA // Operations Research Project in Kenya OR Summary no. 5. Nairobi: Population Council.

Williams, Katherine. "Provider-related barriers to accessing emergency contraception in developing countries: A literature review." Washington, DC: Population Council.

Zhao, Binghai, Qing-Quan Lian, Yanhui Chu, Dianne 0. Hardy, Xiao-Kun Li, and Renshan Ge. "The inhibition of human and rat $11 ß$-hydroxysteroid dehydrogenase 2 by perfluoroalkylated substances," Journal of Steroid Biochemistry and Molecular Biology 125(1-2): 143-147.

\section{OTHER}

"Involving men," Momentum, November.

Population and Development Review 37(3).

Studies in Family Planning 42(3). 
Population Briefs is a research newsletter of the Population Council.

The Population Council conducts biomedical, social science, and public health research and develops reproductive health products. The Council works in three programmatic areas: HIV and AIDS; poverty, gender, and youth; and reproductive health.

\section{(2) Population Council}

Population Council, One Dag Hammarskjold Plaza, New York, New York 10017 www.popcouncil.org

Writer/Editor: Gina Duclayan

Production Manager: Y. Christina Tse

Production Artist: Sura Rosenthal

Copyeditor: Robert Heidel

Editorial Assistant and Circulation: Debra Warn

Cover photo by (C) Richard Lord.

Population Briefs is distributed without charge. Information in this newsletter may be reproduced without permission, provided it is distributed without charge and the source is acknowledged.

To receive e-mail when a new issue of Population Briefs is posted to the Population Council Web site, register at www.popcouncil.org/signup

ISSN 1084-6786

(C) 2011 The Population Council, Inc.

Printed on recycled paper.

\section{POVERTY, GENDER, \& YOUTH}

\section{Bringing Clarity to Gender Equity Programs}

In the past decade, expanding resources have been devoted to fostering gender equity in a variety of social programs, including those dealing with HIV. This effort has been particularly urgent in sub-Saharan Africa, where female/male HIV infection ratios in young populations (aged 15-24) have reached 3-to-1 and sometimes higher. Programs addressing "gender and HIV" vary greatly with regard to target audiences, content, and measurable results. They range from microcredit programs for HIV-positive women to workplace programs seeking to change negative male norms and efforts to increase respect for diverse sexual and gender identities. A team of researchers, led by Population Council social scientist Nicole Haberland and policy analyst Judith Bruce, recently assessed a large subsample of the first generation of programs that address gender and HIV. They made recommendations to shape and improve the next generation of programs.

\section{Girls' and boys' differential risks over the life cycle}

The persistently high female/male HIV infection ratios among young people have numerous causes. Girls' biological and social puberty comes years before boys'. For girls, puberty results in less freedom and fewer choices, while for boys it leads to wider opportunities. This situation puts girls at a higher risk for harm related to restrictive, often exploitative, gender norms. A significant proportion of adolescent girls describe their first sexual experience as forced or tricked. In some countries, especially those in sub-Saharan Africa, the majority of girls aged 10-14 live in urban communities, often with only one or no parent. In some areas, 10 percent or more of girls live with neither parent and do not attend school.

"Although work to establish gender equity and safety is important for all," states Bruce, "we must focus scarce resources on those who are at the highest risk of the worst outcomes at the youngest ages. This frequently means girls in late childhood and early adolescence. 'Gender and HIV' programs are promising vehicles for this human rights and health equity investment."

The researchers examined 63 illustrative gender and HIV programs from across the globe, among them some of the largest and best-known initiatives. Data—about how programs selected their beneficiaries and targeted their interventions and whether, and to what degree, they address the distinct needs of females and maleswere garnered largely through interviews. The researchers used several different scales to rate the strength of each program's approach to confronting gender issues.

continued on page 5 